\title{
EFFECTS OF PROGESTERONE ON BENZENE TOXICITY IN RATS
}

\author{
Yeshvandra VERMA and Suresh Vir Singh RANA \\ Ch. Charan Singh University, Meerut, India \\ Received in May 2007 \\ Accepted in January 2008
}

\begin{abstract}
Benzene is a frequently used industrial solvent. Its toxic manifestations could be modified by sex hormones, but mechanisms of their action are poorly understood. We have examined the influence of progesterone on lipid peroxidation (malondialdehyde), reduced glutathione (GSH), and cytochrome P450 2E1 (CYP2E1) in the liver and kidneys of female rats. Progesterone applied to benzene-treated rats inhibited the formation of reactive oxygen species (ROS), but in ovariectomised benzene-treated rats it significantly increased GSH in the liver. No improvement in CYP2E1 activity was observed in progesterone treated rats. Our results evidence that progesterone changes benzene toxicity (generation of ROS, oxidative stress). However, the probable antioxidative effect of progesterone needs to be confirmed by further studies.
\end{abstract}

KEY WORDS: CYP2E1, glutathione, lipid peroxidation, kidney, liver, oxidative stress, phase-I enzymes, reactive oxygen species

The sex of experimental animals can influence their susceptibility to xenobiotics. In humans, women are more susceptible to the myelotoxic action of benzene than men. These differences have been attributed to the influence of oestrogenic or androgenic hormones on drug-metabolising enzymes (1). Endocrinal disturbances may greatly alter the toxic potential of drugs or other xenobiotics (2-4). Removal of endocrine glands or conditions induced to reduce their activity may also affect drug metabolism. The microsomal metabolising capacity of the liver for a variety of drugs depends on age, diet, strain and sex (5).

A few reports have described the effects of hormones on benzene toxicity. The leucotoxic action of benzene is potentiated by administration of female hormones to male rabbits (6). Oestradiol, on the other hand, reverses the protection against benzene toxicity induced by castration (7). Pregnancy renders rabbits and guinea pigs more vulnerable to the myelotoxic effects of benzene.

Available information confirms that benzene exposure affects serum levels of sex hormones in rat (8). Since benzene toxicity is attributed to the formation of reactive intermediate species and finally to oxidative stress $(9,10)$, endocrinal regulation of its toxicity warrants further study. This is why we carried out a study on the influence of progesterone on benzene toxicity in female rats. This paper brings the results on lipid peroxidation and oxidative stress in the liver and kidneys of female rats subjected to benzene treatments after ovariectomy and progesterone treatment.

\section{MATERIALS AND METHODS}

Female Wistar rats [(150 \pm 20$) \mathrm{g}]$ were procured from the animal facility of Jamia Hamdard, New Delhi. They were kept in laboratory conditions [room temperature $(25 \pm 5)^{\circ} \mathrm{C}$, relative humidity $(50 \pm 10) \%$ and 12 hours light and dark cycle] for two weeks before starting the experiment.

Each rat was housed separately in a polypropylene cage $(4 \mathrm{~cm} \times 27 \mathrm{~cm} \times 13 \mathrm{~cm})$ and given pelleted food 
(Golden Feeds, New Delhi) and tap water ad libitum. All animal treatments and protocols received prior approval by the Institutional Ethical Committee, and followed the standards laid down by the Ministry of Social Justice and Empowerment, Government of India.

\section{Ovariectomy}

Fifteen rats were randomly selected for unilateral ovariectomy following the standard procedure (11). Light ether anaesthesia was used to put the rats to sleep. A single longitudinal skin incision was made on the dorsolateral area at the level of the lower poles of the kidney after shaving the furs with scissors and cleaning with $70 \%$ alcohol. The skin was retracted laterally toward one side and the ovary exposed through a thin muscle mass just below the dorsal muscle mass. Each incision was of minimum length to allow the extrusion of ovary. Ovary was excised and wound was closed. Aseptic procedure was maintained throughout the operation. These rats were kept under observation for two weeks for any post-operational disturbances. After recovery, the animals were used for benzene treatment.

\section{Experimental design}

The rats were divided into six groups, each containing five rats. Four groups of rats were receiving intramuscular benzene injections in sublethal dose of $0.2 \mathrm{~mL}$ per $100 \mathrm{~g}$ body weight every other day for 30 days. Two groups were receiving intramuscular progesterone injections of $0.5 \mathrm{~mL}$ per $100 \mathrm{~g}$ body weight alternately with benzene every other day for 30 days. The first progesterone dose was introduced 24 hours after the first benzene dose. Each experiment in any of the groups lasted 30 days.

Group A consisted of ovariectomised rats receiving benzene and progesterone. Group B consisted of non-ovariectomised rats also receiving benzene and progesterone. Group $\mathrm{C}$ consisted of ovariectomised rats receiving benzene alone. Group $\mathrm{D}$ consisted of non-ovariectomised rats also receiving benzene only. In group $E$ the rats were unilaterally ovariectomised, but received no treatment. Group F consisted of nonovariectomised and untreated controls.

Body weight of each rat in all groups was recorded every day for thirty days, starting with the first benzene dosing. After the scheduled treatments the rats were starved overnight and sacrificed the following morning under light ether anaesthesia. Blood was collected through cardiac puncture and serum was separated by centrifugation. Wet weights of carefully removed liver and both kidneys were recorded on an electronic balance (Sartorius) to calculate the organ/body weight relationship. Homogenates of liver and both kidney samples were prepared in $0.9 \mathrm{~mol} \mathrm{~L}^{-1} \mathrm{NaCl}$ for protein and malondialdehyde determination, in $0.25 \mathrm{~mol} \mathrm{~L}^{-1}$ EDTA for reduced glutathione, and in $1.15 \mathrm{~mol} \mathrm{~L}^{-1} \mathrm{KCl}$ for CYP2E1, using the potter Elvehjem homogeniser. The homogenates were centrifuged accordingly to prepare samples for measurements described below.

\section{Serum progesterone}

Progesterone concentrations in serum samples were estimated by radioimmunoassay using a commercial kit supplied by SPAN Diagnostics Pvt. Ltd. Surat, India.

\section{Protein}

Protein content in the liver and both kidneys was determined applying the method of Lowry et al. (12). Bovine serum albumin (Sigma) was used as the standard.

\section{Lipid peroxidation}

Malondialdehyde as lipid peroxidation product was measured in liver and kidney samples using a method recommended by Jordan and Schenkman (13). Microsomes were separated following the procedure of Schenkman and Cinti (14). The formation of thiobarbituric acid reactive substances (TBARS) was recorded at $532 \mathrm{~nm}$ using a spectrophotometer (Systronics, India). 1,1,3-tetramethoxy propane (Sigma) was used as the standard.

\section{Reduced glutathione}

Reduced glutathione in the liver and kidneys was estimated following the Ellman method (15) using 5'-5' dithiobis-2-nitrobenzoic acid (Sigma, USA). Sulphosalicylic acid was used for protein precipitation. GSH values were evaluated by comparing absorbance values with a standard curve prepared from different GSH concentrations. Absorbance was recorded spectrophotometrically (Systronics, India) at 412 nm.

\section{Assay of CYP2E1 activity}

CYP2E1 activity in microsomal preparations of the liver and kidneys was estimated according to the 
method of Koop (16). Briefly, the reaction mixture consisted of microsomal protein $\left(0.2 \mathrm{mg} \mathrm{mL}^{-1}\right)$, $0.1 \mathrm{~mol} \mathrm{~L}^{-1}$ potassium phosphate, $\mathrm{pH} 6.8,1 \mathrm{mmol} \mathrm{L}^{-1}$ $p$-nitrophenol. Samples were incubated at $37^{\circ} \mathrm{C}$ for 3 min prior to the addition of NADPH to start the reaction. After $10 \mathrm{~min}$, the reaction was stopped with $1.5 \mathrm{~mol} \mathrm{~L}^{-1}$ perchloric acid. Formation of $p$ nitrocatechol was measured spectrophotometrically at $510 \mathrm{~nm}$.

\section{Statistical inference}

Student's $t$-test was used for statistical inferences (17). The values $p \leq 0.05$ were taken as statistically significant.

\section{RESULTS}

The control rats (group F) gained $23.3 \%$ of their initial body weight during the experiment. Ovariectomised rats (groups A, C, and E) did not gain weight over the 30 days of the experiment. Benzenealone-treated rats (group D) lost $10.1 \%$ of their initial body weight during the experiment. Ovariectomised benzene-treated rats (groups A and C) did not gain weight during the experiment and their final weights were significantly lower than in control rats.
Administration of progesterone to ovariectomised plus benzene-treated rats (group A) also failed in promoting their growth. However, a gain in weight similar or even greater than in control was observed in benzene plus progesterone-treated rats (group B) (Figure 1).

Organ/body weight relationship was calculated in rats of all the six groups. The lowest hepatosomatic values were recorded in benzene treated rats (group D) and were similar to controls (group F). Administration of benzene to ovariectomised rats (group C) also reduced the hepatosomatic index in comparison to ovariectomised control rats (group E), but progesterone administration to ovariectomised and benzene-treated rats (group A) increased the hepatosomatic values in comparison to benzenetreated rats (group D). Renosomatic indices also decreased in benzene-treated rats (group D) in comparison to ovariectomised plus benzene-treated rats (group C). The highest renosomatic indices were recorded in benzene plus progesterone-treated ovariectomised rats (group A). Ovariectomy alone increased the weight of kidneys (group E, Figure 2).

Unilateral ovariectomy as well as benzene-alone treatment (groups E and D) decreased concentrations of serum progesterone. Progesterone administration to benzene-treated rats (group B) lowered serum progesterone concentrations even more (Table 1). In contrast, benzene administration to ovariectomised

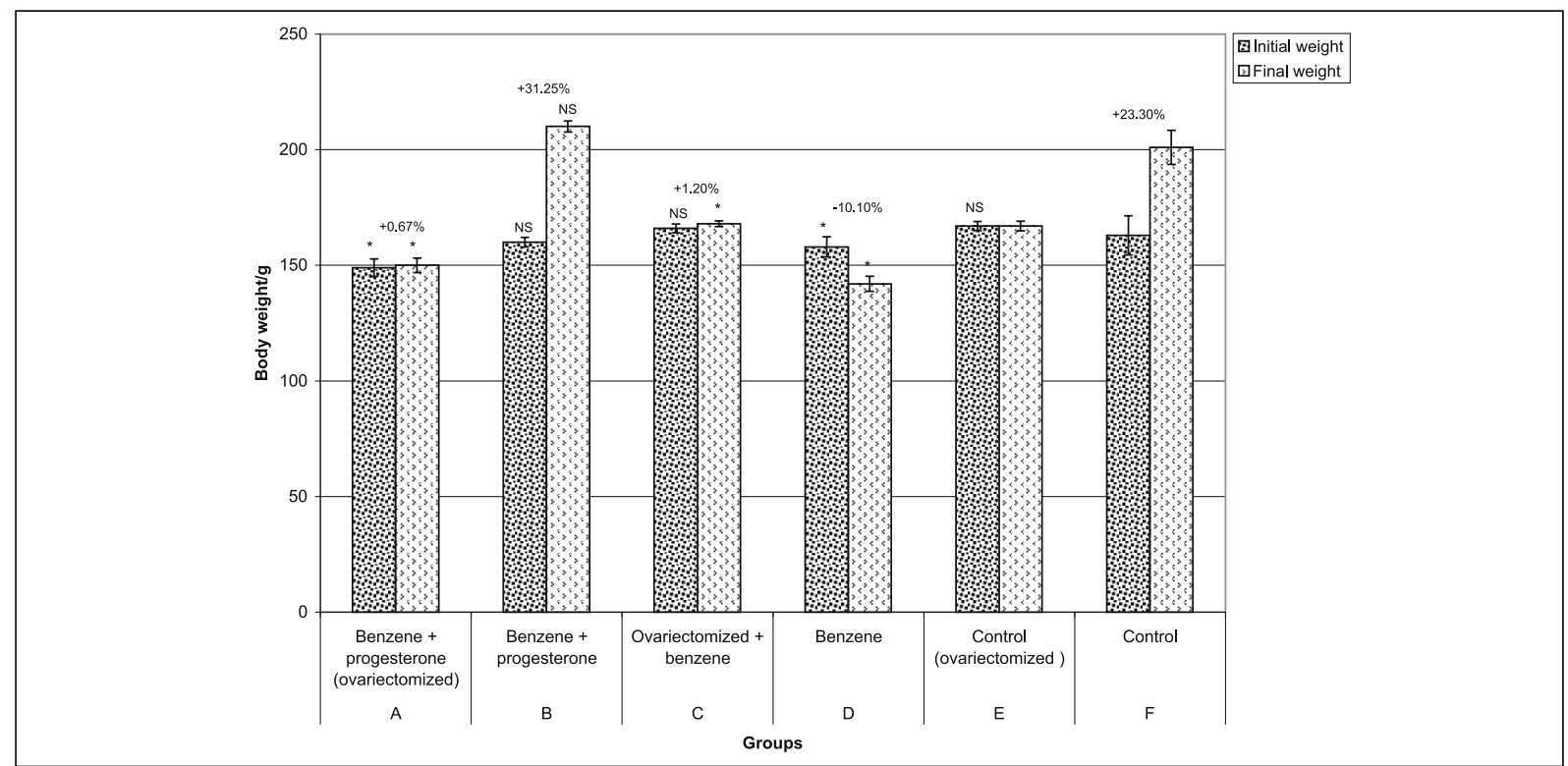

Figure 1 Effect of benzene and progesterone on body weight of rats. Results are expressed as mean $\pm S E(n=5)$. Values over the bars show the differences between initial and final body weight per group in percentages. * Denotes values significantly different from corresponding weight of control (group F, $p \leq 0.05$ ).

NS - difference not significant.

Inter-group comparisons between groups $D: B ; B: A ; D: C$ show significantly different $(p<0.05)$ final weights. The final weights are not significantly different between groups $C$ and $A(p \leq 0.05)$. 
Table 1 Concentrations of serum progesterone in experimental rats

\begin{tabular}{|l|l|c|}
\hline Group & Treatment & $\begin{array}{c}\text { Progesterone / } \\
\mu \mathrm{g} \mathrm{mL}^{-1}\end{array}$ \\
\hline A & $\begin{array}{l}\text { Ovariectomised + } \\
\text { benzene + progesterone } \\
\text { Benzene + } \\
\text { Brogesterone } \\
\text { Ovariectomised + } \\
\text { benzene } \\
\text { Benzene }\end{array}$ & $7.59 \pm 0.42 \pm 0.077^{*}$ \\
D & $\begin{array}{l}\text { Ovariectomised - } \\
\text { control } \\
\text { E }\end{array}$ & $11.59 \pm 0.006^{*}$ \\
F & Control & $5.45 \pm 0.006^{*}$ \\
\hline
\end{tabular}

Results are expressed as mean $\pm S E(n=5)$.

* Denotes values significantly different from control (group $F, p \leq 0.05$ ). Inter-group comparisons between groups $D: B ; B: A ; C: A ; D: C$ show values significantly different at $p \leq 0.05$.

rats (group C) increased serum progesterone. Administration of progesterone to ovariectomised benzene-treated rats (group A) increased serum progesterone level even more (Table 1).
Ovariectomy alone (group E) increased, though not significantly, protein concentration in the liver and decreased it in the kidneys. Treatment with benzene (group D) did not change protein concentrations in the liver or the kidneys. Administration of progesterone to benzene-treated rats (group B) as well as to benzenetreated ovariectomised rats (group A) lowered total protein concentration in the kidneys and increased it in the liver (Table 2).

Ovariectomy in untreated rats (group E) increased lipid peroxidation in the liver, but did not affect it in the kidneys. Benzene exposure (group D) also increased lipid peroxidation in the liver and decreased it in the kidneys. Benzene administration to ovariectomised rats (group C) lowered lipid peroxidation in the liver and increased it in the kidneys when compared to rats treated with benzene alone (group D). The highest levels of malondialdehyde were recorded in ovariectomised rats treated with benzene plus progesterone (group A, Table 3).

Compared to control rats (group F), ovariectomy (group E) increased GSH level in the liver and decreased it in the kidneys. Administration of benzene to ovariectomised rats (group C) increased GSH level in the liver and the kidneys in comparison to benzene-

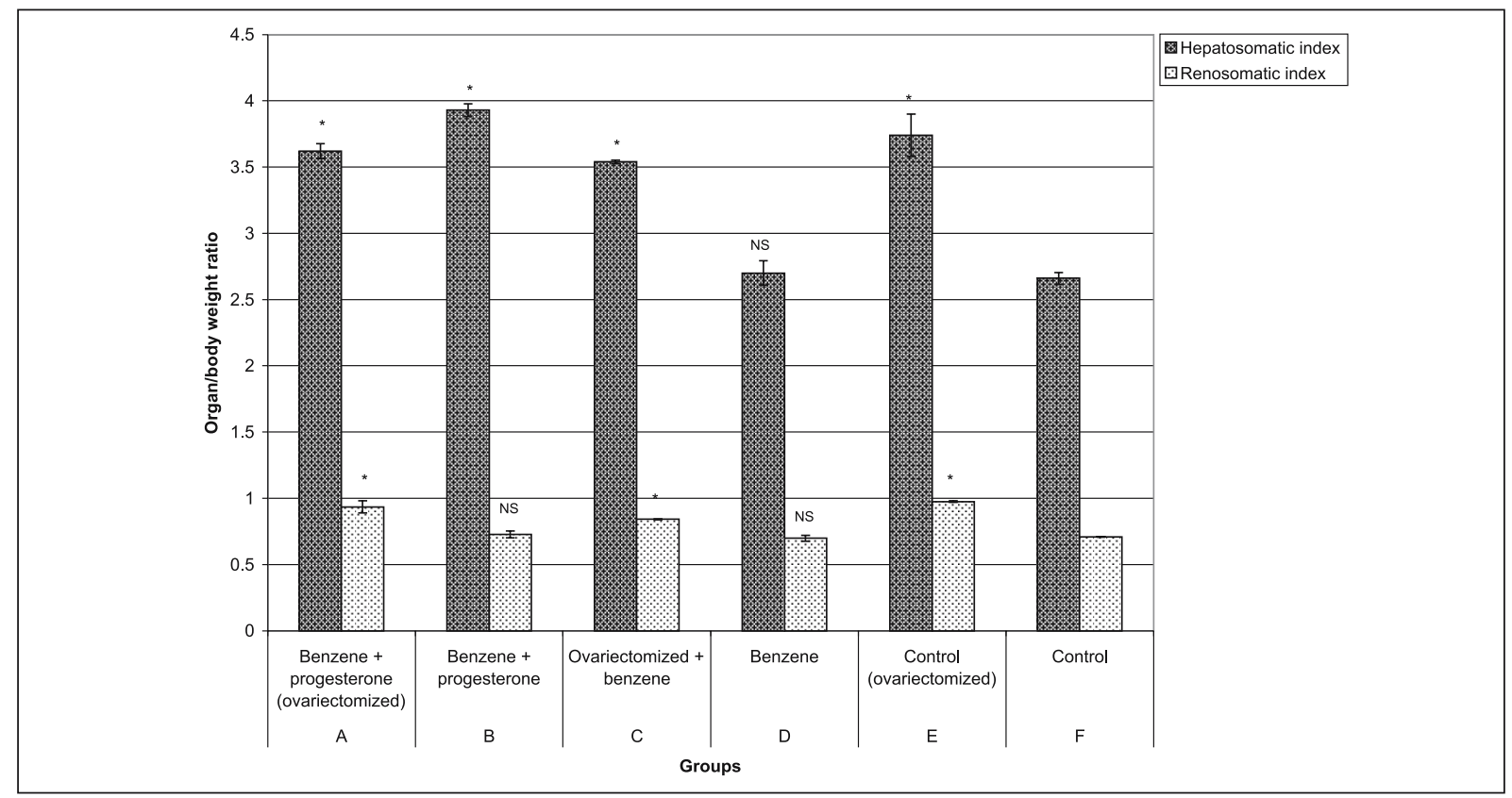

Figure 2 Effect of benzene and progesterone on hepatosomatic and renosomatic indices in rats. Results are expressed as mean $\pm S E(n=5)$. * Denotes values significantly different from corresponding control subgroups (of group F, $p \leq 0.05$ ).

NS - difference not significant.

Inter-group comparisons of hepatosomatic indices show significant differences between groups $D: B ; B: A ; D: C$; and non-significant differences between groups $C$ and $A$ at $p \leq 0.05$. Values of renosomatic indices between groups $D: B ; B: A ; C: A ;$ and $D: C$ are significantly different at $p \leq 0.05$. 
Table 2 Concentrations of protein $(\mathrm{g} / 100 \mathrm{~mL})$ in the liver and kidneys of experimental rats

\begin{tabular}{|l|l|c|c|}
\hline Group & Treatment & Liver & Kidneys \\
\hline A & Ovariectomised + benzene + progesterone & $23.04 \pm 0.24^{*}$ & $11.96 \pm 1.17^{*}$ \\
B & Benzene + progesterone & $19.24 \pm 8.26^{*}$ & $11.13 \pm 0.06^{\mathrm{NS}}$ \\
C & Ovariectomised + benzene & $18.58 \pm 1.38^{\mathrm{NS}}$ & $7.71 \pm 0.63^{*}$ \\
D & Benzene & $12.53 \pm 1.59^{\mathrm{NS}}$ & $15.73 \pm 2.25^{\mathrm{NS}}$ \\
E & Ovariectomised - control & $18.14 \pm 4.06^{\mathrm{NS}}$ & $5.89 \pm 1.32^{*}$ \\
F & Control & $11.39 \pm 2.94$ & $13.74 \pm 0.02$ \\
\hline
\end{tabular}

Results are expressed as mean $\pm S E(n=5)$.

* denotes values significantly different from control (group $F, p \leq 0.05$ ).

NS difference not significant compared to control value (group F).

Inter-group comparisons of protein concentrations in the liver and kidneys between groups C:A; C:D show significant differences, and between groups D:B; B:A non-significant differences at $p \leq 0.05$

Table 3 Mass fractions of malondialdehyde ( $\mu \mathrm{g} \mathrm{mg}^{1}$ protein) in the liver and kidneys of experimental rats

\begin{tabular}{|l|l|c|c|}
\hline Group & Treatment & Liver & Kidneys \\
\hline A & Ovariectomised + benzene + progesterone & $2.27 \pm 0.229^{*}$ & $1.61 \pm 0.083^{*}$ \\
B & Benzene + progesterone & $0.60 \pm 0.001^{*}$ & $0.95 \pm 0.100^{*}$ \\
C & Ovariectomised + benzene & $0.87 \pm 0.005^{*}$ & $0.76 \pm 0.059^{*}$ \\
D & Benzene & $0.94 \pm 0.165^{*}$ & $0.56 \pm 0.092 \mathrm{NS}$ \\
E & Ovariectomised - control & $1.82 \pm 0.012^{*}$ & $1.12 \pm 0.002 \mathrm{NS}$ \\
F & Control & $0.27 \pm 0.001$ & $1.13 \pm 0.380$ \\
\hline
\end{tabular}

Results are expressed as mean $\pm S E(n=5)$.

* Denotes values significantly different from control (group $F, p \leq 0.05$ ).

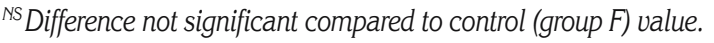

Liver level differences between groups $D$ and $B$ are not significant.

Liver and kidney level differences between B:A; C:A; D:C are not significant.

only-treated rats (group D) and to ovariectomised rats (group E). However, administration of progesterone to ovariectomised and benzene-treated rats (group A) reduced GSH level in the liver and kidneys when compared to ovariectomised plus benzene-treated rats (group C, Table 4).

Ovariectomy (group E) decreased the activity of CYP2E1 in the liver and the kidneys. Benzene treatment (group D) also inhibited CYP2E1 in both the liver and the kidneys. Its activity further declined with progesterone treatment in groups A and B (Table 5).

\section{DISCUSSION}

Hormonal status greatly determines the responsiveness of an organism to different agents, including toxic or carcinogenic. This is evidenced by the action of endogenous sex hormones (18) and further supported by observations of changed susceptibility of experimental animals to toxic or carcinogenic agents upon administration of various steroid hormones. The biochemical basis of such hormonal effects is often considered to be changed metabolic pattern of the toxic agents in the liver (19, 20). Pretreatment with steroid hormones resulted in manifold increase in the activity of hepatic microsomal enzymes, altering thus the detoxification process of a foreign agent. Enzyme activities can also be stimulated or reduced by the treatment of sex hormones (18, 21-23).

Testosterone was found to be the main regulator in mice, whereas in rats this role seems to belong to oestradiol (24). In our experiments, benzene administration depleted progesterone in rats. Conversely, benzene administration to unilaterally ovariectomised rats enhanced serum progesterone concentrations (Table 1). There may be several reasons 
for this increase. Ovariectomy is known to increase the activity of $3-\beta$-hydroxysteroid dehydrogenase (25). The activity of this enzyme is governed by the level of progesterone present in circulation. Since progesterone levels would fall immediately after ovariectomy (26), some compensatory mechanism is likely to occur. Even in normal rats, progesterone levels are constantly changing, being higher in late prooestrus and lower in early oestrus (27). Progesterone secreted by the adrenal glands in sufficient quantities maintains plasma progesterone concentration in ovariectomised rats (28).

In our study, we investigated the influence of progesterone on the metabolic disposition of benzene in terms of lipid peroxidation. Results in the liver showed that ovariectomy enhanced the formation of reactive oxygen species (ROS) (Table 3). Kato et al. (29) found reduced formation of ROS under the influence of progesterone. In our experiments, however, progesterone administered to benzenetreated ovariectomised rats induced maximum peroxidative injury in the liver and in the kidneys (Table 3 ). These changes in lipid peroxidation might have occurred because there was a considerable time lag between ovariectomy and progesterone treatment.

Hormonal influence on phase I metabolic enzymes was expected to change benzene toxicity. CYP2A1 catalyzes oxidative metabolism of testosterone, progesterone, and androstenedione in a highly regionspecific and stereoselective manner (30). Expression of sex-dependent CYP450 enzymes is also under endocrine control. Oestrogen treatments are known to increase CYP2A1 activity. The antagonistic effects of androgens and estrogens on CYP2A1, therefore, maintain the sex-dependent expression of CYP450 isoenzymes in postpubertal rats. Ovariectomy at birth decreases CYP450 2A1 (31). Both androgen and oestrogen suppress CYP2E1 expression (32). Hypophysectomy leads to increased CYP2E1 expression (23). The level at which different hormonal factors act on the CYP2E1 gene and gene products is not well understood. Changes in enzyme levels were associated with alterations in the endocrine system (33). Available literature indicates that CYP2E1 is expressed in higher amounts in male than female rats (1). In both sexes, there is an uneven expression of CYP2E1 within the liver acinus. In male rats, CYP2E1 is localised in a 4- to 5-cell thick layer surrounding the terminal hepatic venules (22). Our results suggest that oestrogens influence benzene toxicity not involving CYP450 isoenzymes. These observations are supported by Harris et al. (34) who suggested that only a few CYP450 isoenzymes associated with biotransformation of drugs are under oestrogenic control. Similar observations were found in rats treated with lindane (35).

Observations on reduced glutathione support results on lipid peroxidation. Benzene increased GSH levels in the liver and kidneys (Table 4) of ovariectomised rats. However, this increase was not significant in non-ovariectomised rats treated with benzene plus progesterone in comparison with control rats. Progesterone administered to benzenetreated ovariectomised rats improved, though not significantly, GSH levels in the liver in comparison with benzene-alone-treated rats. However, no such improvement was recorded in the kidneys.

The significance of this study lies in two facts. Firstly, benzene toxicity is influenced by progesterone. Increased levels of GSH in the liver of benzene-

Table 4 Mass fractions of reduced glutathione (GSH) $\left(\mu \mathrm{g} \mathrm{g}^{1}\right.$ wet tissue) in the liver and kidneys of experimental rats

\begin{tabular}{|l|l|c|c|}
\hline Group & Treatment & Liver & Kidneys \\
\hline A & Ovariectomised + benzene + progesterone & $0.106 \pm 0.0079^{*}$ & $0.117 \pm 0.0006^{\mathrm{NS}}$ \\
B & Benzene + progesterone & $0.099 \pm 0.0077^{\mathrm{NS}}$ & $0.108 \pm 0.0141^{\mathrm{NS}}$ \\
C & Ovariectomised + benzene & $0.138 \pm 0.0062^{*}$ & $0.145 \pm 0.0082^{*}$ \\
D & Benzene & $0.087 \pm 0.0087^{\mathrm{NS}}$ & $0.117 \pm 0.0010^{*}$ \\
E & Ovariectomised - control & $0.080 \pm 0.0008^{*}$ & $0.090 \pm 0.0008^{*}$ \\
F & Control & $0.072 \pm 0.0006$ & $0.100 \pm 0.0053$ \\
\hline
\end{tabular}

Results are expressed as mean $\pm S E(n=5)$.

* Denotes values significantly different from control (group F, $p \leq 0.05$ ).

NS Difference not significant compared to control (group F) value.

Liver and kidney level differences between groups C:A; D:C are significant at $p \leq 0.05$. 
Table 5 Contents of cytochrome P450 2E1 ( $\mu$ mol mg ${ }^{1}$ microsomal protein) in the liver and kidneys of experimental rats

\begin{tabular}{|l|l|c|c|}
\hline Group & Treatment & Liver & Kidneys \\
\hline A & Ovariectomised + benzene + progesterone & $0.083 \pm 0.004^{*}$ & $0.032 \pm 0.002^{*}$ \\
B & Benzene + progesterone & $0.092 \pm 0.005^{*}$ & $0.046 \pm 0.001^{*}$ \\
C & Ovariectomised + benzene & $0.090 \pm 0.007^{*}$ & $0.048 \pm 0.001^{*}$ \\
D & Benzene & $0.106 \pm 0.003^{*}$ & $0.070 \pm 0.004^{*}$ \\
E & Ovariectomised - control & $0.181 \pm 0.016^{*}$ & $0.084 \pm 0.002^{*}$ \\
F & Control & $0.216 \pm 0.001$ & $0.104 \pm 0.001$ \\
\hline
\end{tabular}

Results are expressed as mean $\pm S E(n=5)$.

* Denotes values significantly different from control (group $F, p \leq 0.05$ ).

The difference between contents in groups D:B; B:A is significant for the liver, but not for the kidneys at $p \leq 0.05$; it is not significant in groups $C$ : $A$ and $D: C$ for the liver.

and progesterone-treated rats, even though not significantly, favour the protective role of progesterone against benzene toxicity. Furthermore, ovariectomised rats could be used as an in vivo model to study the mechanism of benzene toxicity in working women with no or deficient oestrogen supply (36).

\section{Acknowledgements}

The authors are thankful to the Department of Science and Technology (Government of India) for financial support to Yeshvandra Verma (Grant no. SR/FT/L-52/2004).

\section{REFERENCES}

1. Kobliakov V, Popova N, Rossi L. Regulation of the expression of the sex-specific isoforms of cytochrome P450 in liver. Eur J Biochem 1991;195:585-91.

2. Rana SVS, Rastogi N. Effects of cadmium on liver function in diabetic rats. Toxicol Ind Health 1998;14:473-7.

3. Rana SVS, Rastogi N. Antioxidative enzymes in the liver and kidney of diabetic rats and their implications in cadmium toxicity. Physiol Chem Phys Med NMR 2000;32:67-74.

4. Allen T, Rana SVS. Oxidative stress by inorganic arsenic: modulation by thyroid hormones in rat. Comp Biochem Physiol (Part C) 2003;135:157-62.

5. Larsen MC, Jefcoate CR. Phenobarbital induction of CYP2B1, CYP2B2 and CYP3A1 in rat liver: genetic differences is a common regulatory mechanism. Arch Biochem Biophys 1995;321:467-76.

6. Desoille H, Philbert M, Albahary C. Effects of hormones on chronic benzene poisoning in rabbits. II. Influence of sex, castration, homologous or heterologous sex hormone therapy on leukocytosis in rabbits exposed to short-term (6 weeks) benzene poisoning. Arch Mal Path 1962;23:209-18.

7. Desoille H, Philbert M, Albahary C. Factors altering the toxicity and metabolism of xenobiotics In: De Bruin A, editor. Biochemical toxicology of environmental agents. Amsterdam: Elsevier/North Holland Biomedical Press; 1976. p. 271-301.

8. Dere E, Gyborova S, Aydin H. The effect of benzene on serum hormones and the activity of some enzymes in different tissues of rats. Acta Veterinaria 2003;53:87101.

9. Uysal M, Yalcin AS, Tokar NK, Keryer-Uysal M, Aykac G. Lipid peroxidation in liver and plasma of rats treated with benzene. IRCS Med Sci 1986;14:772-80

10. Rana SVS, Verma Y. Biochemical toxicity of benzene. J Environ Biol 2005;26:157-68.

11. Sulman FG. Intravaginal assay of estrogens. Endocrinology 1952;50:61-7.

12. Lowry OH, Rosebrough NJ, Farr AL, Randall RJ. Protein measurement with the folin phenol reagent. J Biol Chem 1951;193:265-75.

13. Jordan RA, Schenkman JB. Relationship between malondialdehyde production and arachidonate consumption during NADPH supported microsomal lipid peroxidation. Biochem Pharmacol 1982;31:1393400.

14. Schenkman JB, Cinti DL. Preparation of microsomes with calcium. Methods Enzymol 1978;52:83-9.

15. Ellman GL. Tissue sulfhydryl groups. Arch Biochem 1959;82:70-7.

16. Koop DR. Hydroxylation of para-nitrophenol by rabbit ethanol-inducible cytochrome-P450 isozyme 3A. Mol Pharmacol 1986;29:399-404.

17. Fisher RA. Statistical Methods for Research Workers. $2^{\text {nd }}$ edition. London: Oliver and Boyd; 1950.

18. von Deimling O. Enzymarchitektur der Niere und Sexualhormone [Effect of sex hormones on enzyme structure in the liver, in German]. Progr Histochem Cytochem 1970;1:1-50. 
19. El Defrawy El Masry S, Cohen GM, Mannering GJ. Sex-dependent differences in drug metabolism in the rat. I. Temporal changes in the microsomal drug-metabolizing system of the liver during sexual maturation. Drug Metab Dispos 1974;2:267-78.

20. El Defrawy El Masry S, Mannering GJ. Sex dependent differences in drug metabolism in the rat. II. Qualitative changes produced by castration and the administration of steroid hormones and phenobarbital. Drug Metabol Disp 1974;2:279-84.

21. Kumar S, Rana SVS. Influence of testosterone and progesterone on fatty liver of rats treated with a few halogenalkanes. Indian J Exp Biol 1988;26:811-3.

22. Rana SVS, Rastogi S. Effect of carbontetrachloride on collagen in the liver of parathyroidectomized rat. Zool Jahrb Abt Anat Ontog Tiere 1991;121:259-65.

23. Verma Y, Rana SVS. Sex-differences in oxidative stress induced by benzene in rats. Indian J Exp Biol 2004;42:117-20.

24. Rosen H, Jameel ML, Dee C, Barkan AL. Regulation by oestradiol of serum levels of $\mathrm{LH}$ and FSH and pituitary levels of gonadotrophin-releasing hormone receptors after ovariectomy in the rat. J Endocrinol 1989;123:249-56.

25. Hornsby PJ. Steroid and xenobiotic effects on the adrenal cortex: mediation by oxidative and other mechanisms. Free Radic Biol Med 1989;6:103-15.

26. Bedwani JR, Marley PB. Effect of ovariectomy and of various hormones on the synthesis of progesterone by the guinea pig placenta in vitro. J Reprod Fertil 1971;26:343-9.

27. Daly TJM, Kramer B. Alteration in rat vaginal histology by exogenous gonadotrophins. J Anatomy 1998;193:469-72.
28. Feder HH, Resko JA and Goy RW. Progesterone levels in the arterial plasma of pre-ovulatory and ovariectomized rats. J Endocrinol 1968;41:563-9.

29. Kato N, Sugino N, Takiguchi S, Kashida S, Nakamura Y. Roles of reactive oxygen species in the regulation of luteal function. Rev Reprod 1997;2:81-3.

30. Wood AW, Ryan DE, Thomas PE, Levin W. Regio- and stereoselective metabolism of two C19 steroids by five highly purified and reconstituted rat hepatic cytochrome P450 isozymes. J Biol Chem 1983;258:8839-47.

31. Garcia-Agundez, J.A., Benitez, J. Sex and age related differences in aminopyrine $\mathrm{N}$-demethylase activity in DA- and Wistar-strain rat liver microsomes. Effect of ovariectomy. Xenobiotica 1991;755-762.

32. Porter TD, Coon MJ. Cytochrome P450. Multiplicity of isoforms, substrates, and catalytic and regulatory mechanisms. J Biol Chem 1991;266:13469-72.

33. Kato R, Kamataki T. Cytochrome P450 as a determinant of sex difference of drug metabolism in the rat. Xenobiotica 1982;12:787-800.

34. Harris RZ, Benet LZ, Schwartz JB. Gender effects in pharmacokinetics and pharmacodynamics. Drugs 1995;50:222-39.

35. Luis FOH, Adolfo SS, Mariano EC, Manno M, Albores A. Ovariectomy modulates the response of some cytochrome P450 isozymes to lindane in the rat. Toxicol Lett 2001;124:91-9.

36. Dodge JA, Glasebrook AZ, Magee DE, Phillips DL, Sato M, Short LL, Bryant HU. Environmental estrogens effects on cholesterol lowering and bone in the ovariectomized rat. J Steroid Biochem Molec Biol 1996;59:155-61. 


\section{Sažetak}

\section{UTJECAJ PROGESTERONA NA TOKSIČNOST BENZENA U ŠTAKORA}

Benzen se u industriji često rabi kao otapalo. Zna se da na njegovu toksičnost mogu utjecati spolni hormoni, ali su mehanizmi njihova djelovanja još uvijek slabo poznati. Ispitali smo utjecaj progesterona na peroksidaciju lipida (malondialdehida), pad razina glutationa te aktivnost citokroma P450 2E1 (CYP2E1) u jetri i bubrezima štakorica. Primjena progesterona u štakorica koje su prethodno primile benzen inhibirala je stvaranje reaktivnih molekula kisika (engl. reactive oxygen species, krat. ROS), ali je u štakorica s ovariektomijom koje su također primile benzen doveo do značajnoga rasta glutationa u jetri. U štakorica koje su primile progesteron nije zamijećena poboljšana aktivnost izoeznima CYP2E1. Naši rezultati potvrđuju da progesteron utječe na toksičnost benzena (stvaranje ROS-a i oksidativni stres). Međutim, tek u budućim istraživanjima valja potvrditi djeluje li progesteron antioksidativno.

KLJUČNE RIJEČI: bubrezi, CYP2E1, enzimi faze I, glutation, jetra, oksidativni stres, peroksidacija lipida, reaktivna molekula kisika, ROS

\section{CORRESPONDING AUTHOR:}

Suresh Vir Singh Rana, Ph.D.

Department of Zoology

Ch. Charan Singh University

Meerut - 250004 India

E-mail: sureshus_rana@yahoo.com 